\title{
The Steel Industry of Japan
}

\section{Outline}

In 1960 crude steel production in Japan amounted to 22.1 million tons - an increase of $33 \%$ as compared with 16.6 million tons in 1959, thereby ranking fifth in the world. Likewise, production of pig iron in 1960 was 11.9 million tons, 26\% more than the 9.4 million tons of the previous year.

The progress made by the Japanese iron and steel industry since the beginning of the 20th century is amazing. It was in 1887 that the first blast furnace was successfully blown in at Kamaishi. In 1890 the first open hearth was installed at Yokosuka Naval Arsenal and in 1901, under governmental management, the first integrated iron and steel plant was put into operation. This one steel plant accounted for more than half of the nation's annual production.

At about this time private steel companies came into being. This trend was progressive during World War I and in spite of the reactionary panic following the war boom, steel production continued to ascend year after year.

In 1934, the government-operated steel plant was merged with 6 private steel-producing concerns to form the Japan Iron and Steel Co., Ltd., a semiofficial enterprise. This new company, at the time of its formation, had a production capacity for pig iron and steel equal to $93 \%$ and $53 \%$ respectively of the national production capacity.

This company dominated the Japanese iron and steel industry for the next sixteen years until it was split into two private steel companies in 1950 as a result of the law for the elimination of excessive concentration of economic power.

By the end of World War II iron and steel production came to a virtual standstill. Through the concerted efforts of the government and industrialists, however, the industry made rapid progress toward rehabilitation and in a few years was able to break all the pre-war production records.

During 1960 the world produced 344 million tons of steel, of which $28 \%$ was produced by the Americas, 30\% by Western Europe (including U. K.), $26 \%$ by Eastern Europe and the U.S.S.R., and 13\% by Asia.

The great distances, 5,000 miles at minimum, that separate the steel centers of Europe and the Americas from Eastern and Southeastern Asia place the Japanese iron and steel industry in a highly important role for the economic development of Asia.

Raw materials used by the Japanese iron and steel industry come not only from Asia but all the way from the Americas. The finished products in turn are exported to Europe and the Americas in addition to those countries in South Eastern Asia.

\section{Raw Materials}

Although Japan's iron ore production is limited to approximately 1.2 million tons annually, Japan possesses huge iron sand and pyrite reserves. Considerable progress has been made since the war end based on an effective utilization of iron-bearing materials of poor quality. The use of domestic materials has increased in recent years to a point where nearly $30^{\circ}$ of the industry's requirements has been met.

Because of unexpectedly increased production of iron and steel in 1960, the import of raw materials was increased further in the same year as compared with 1959. The importation of iron ore in 1960 was 14.9 million tons, or a 43 increase over that of the previous year. Supply of iron ore was increased from such areas as Malaya, India, Goa, South America and North America.

The development of the Japanese steel industry, however, will depend upon the continuous importation of considerable quantities of foreign ores. Japan fortunately has easy access to the iron ore resources in Southeastern Asia where she is the biggest iron ore buyer. An agreement for the joint development of Indian iron ore was signed by India and Japan for a period of 10 years, beginning in 1964. In addition, during 1958, Japanese firms investigated the possibilities of developing iron ore mines in Malaya, the Dominican Republic and Chile.

Ores are transported at low cost to Japanese plants which are positioned in those coastal areas possessing top harbor facilities. The construction of ore carriers plus the expansion of existing port facilities, all of which is under way, will further reduce the cost of imported ores.

In order to make the most of the better foreign ores imported into Japan, laboratory studies have been conducted to determine the best use that can be made of poor ores, iron sand and high grade ore. Technical improvement in the treatment of iron-bearing materials has promoted the consumption of iron sand and pyrite cinders in 1960 to 1.6 million tons and 1.4 million tons respectively.

Despite the fact that Japan has considerable coal reserves, it does not have sufficient high grade coking coal to meet the ever increasing demands of the steel industry. Imported coals must be blended with those mined indigenously to produce the coke for blast furnaces. In 1960 the iron and steel industry consumed 11.3 million tons of coking coal, $51 \%$ of which came from foreign sources.

This paper is based on a booklet "The Steel Industry of Japan" Mar. 1961, published by the Japan Iron \& Steel Federation. 
Japan has, since World War II, become increasingly dependent upon the United States for its coking coal which comprises today $70-90 \%$ of its coking coal imports.

In 1960, the Japanese iron and steel industry imported 6.1 million tons of coking coal which is $58 \%$ higher than that of the previous year. Most of the increased import was covered by the increased supply from the U.S.A. amounting to 4,307 thousand tons, or a $38 \%$ increase over the previous year. At the same time the increase in import of Australian coal was also remarkable.

Recently, as a result of investigations conducted in Australia, an agreement was signed with that country to import 2 million tons of high-grade coking coal. This agreement, signed at the end of 1958, will extend over a period of five years.

The supply of iron and steel scrap is of vital importance to the iron and steel industry in Japan where steel is chiefly made in open hearth furnaces. Japan used to import 1-2 million tons of scrap annually from the United States from the mid1930 's on. After the war, as steel production rose, the requirement for scrap increased sharply.

The consumption of steel scrap in 1960 was 13.2 million tons, an increase of $32 \%$ over the previous year. To meet the increased requirements, import of scrap in 1960 reached 4.3 million tons or $5.4 \%$ over that of $1959.71 \%$ of the scrap import was accounted for by the supply from the U.S.A.

Projects are currently under way, however, to reduce the consumption of scrap by installation of top-blown oxygen converters, which of course require more pig iron, and in turn, installation of new blast furnaces.

\section{Production}

Soon after the war, the Japanese iron and steel industry was in a state of complete paralysis. The production of iron and steel was at a virtual standstill due to the economic disorder of the nation and the difficulty in procuring raw materials.

In those early years, the pace of recovery was not rapid. As the general economy recovered, however, so did the iron and steel industry. The outbreak of the Korean War in 1950 provided much assistance in further rehabilitation and development of the Japanese iron and steel industry. The worldwide economic recession that appeared after the Korean cease-fire had little effect on the Japanese iron and steel industry where an investment boom had already started. In 1960, the iron and steel industry of Japan broke all past production records with 22.1 million tons of crude steel, 11.9 million tons of pig iron, 15.7 million tons of ordinary rolled steel and 1.1 million tons of hotrolled special steel. The remarkable increase in steel production was due to the favorable trend of the national economy. Gross national production of Japan was increased by $13.6 \%$ in fiscal year 1960 , supported by an increase in general export and the unexpectedly large growth of the ultimate demand centering around the increase of personal consumption expenditures.

As war scrap supplies ran short, requirements for pig iron increased to a point where considerable quantities had to be brought in from abroad. The proportion of pig iron production to that of crude steel production has shown a notable increase in the past decade from $36 \%$ in 1946 to around 55$60 \%$ in recent years. In view of the difficulty in obtaining scrap, projects are under way to install converters which produce steel without using scrap and erecting new blast furnaces to increase the production of pig iron. Of the 11,896,233 tons of pig iron produced in $1960,95 \%$ was made in blast furnaces and $4 \%$ in electric furnaces. $68 \%$ of steel production comes from open hearth furnaces. Steel production in 1960, divided by type of furnace, is shown in Table II.

Out of a total crude steel production of 22.1 million tons, $95 \%$ went to rolling mills and forgings with the balance ( $5 \%$ ) going to foundries.

In 1960 the production of ordinary rolled steel increased approximately $32 \%$ from the previous year to 15.7 million tons. The 1960 production of hot-rolled special steel increased to 1.1 million tons, an increase of $28 \%$ from the previous year. Among various ordinary steel products, remarkable gain was noted in the production of trench

Table I. Iron and steel production since 1946

(Unit: 1,000 metric tons)

\begin{tabular}{c|c|c|c} 
& Pig iron & Crude steel & Rolled steel \\
\hline Previous record & $4,256(1942)$ & $7,650(1943)$ & $4,810(1943)$ \\
1946 & 203 & 557 & 426 \\
1947 & 347 & 952 & 636 \\
1948 & 808 & 1,715 & 1,201 \\
1949 & 1,549 & 3,111 & 2,220 \\
1950 & 2,233 & 4,839 & 3,556 \\
1951 & 3,127 & 6,502 & 4,898 \\
1952 & 3,474 & 6,988 & 5,051 \\
1953 & 4,518 & 7,662 & 5,644 \\
1954 & 4,608 & 7,750 & 5,765 \\
1955 & 5,217 & 9,408 & 7,129 \\
1956 & 5,987 & 11,106 & 8,616 \\
1957 & 6,815 & 12,570 & 9,891 \\
1958 & 7,394 & 12,118 & 9,479 \\
1959 & 9,446 & 16,629 & 12,699 \\
1960 & 11,896 & 22,138 & 16,844 \\
& & &
\end{tabular}

Table II. Steel production by type of furnace in 1960

\begin{tabular}{l|r|r}
\hline Open hearth steel & 15,045 & $68.0 \%$ \\
\hline Converter steel & 2,629 & $11.9 \%$ \\
\hline Electric furnace steel & 4,464 & $20.1 \%$ \\
\hline$\quad$ Total & 22,138 & $100.0 \%$ \\
\hline
\end{tabular}


sheets and light gage steels, bars, strip, plates, and wire rods.

\section{Modernization and Productivity}

The first modernization program for the iron and steel industry was carried out during the period 1951 through 1956. This program, costing 355 million dollars, made great contributions toward the increase of steel production.

In view of the growing steel demand from home industries, the iron and steel industry launched in 1956 a second long-term rationalization program costing 1.9 billion dollars in response to the 5 year economic expansion program drafted by the Government.

Under the second rationalization program 8 blast furnaces including those of 1,500-ton capacity, 13 converters, 6 blooming mills, 4 continuous hot strip mills, and 2 continuous cold strip mills have been installed.

The production capacity of the Japanese iron and steel industry has rapidly been increased through both the first and the second rationalization programs. New powerful mills and techniques have been introduced mainly from the U.S.A., resulting in a remarkable improvement in the operational technique. The coke consumption per ton of pig iron throughout the country was decreased from $838 \mathrm{~kg}$ in 1953 to $617 \mathrm{~kg}$ in 1960, and the heat consumption per ton of sound ingot in open hearth from 1.36 million kcal in 1953 to 0.71 million kcal in 1960. One of the more efficiently operated blast furnaces showed a coke ratio of $497 \mathrm{~kg}$ and one of the open hearth furnaces recorded a fuel consumption of 0.31 million kcal. Even during the course of one year in 1960, the coke ratio, pig iron output per cubic meter of blast furnace inner volume and operation rate of strip mills have been remarkably improved so that the year-end figures surpassed greatly those of the beginning of the year.

To meet the ever increasing steel requirements, the iron and steel industry of Japan is currently planning another long-term expansion program for the future, which is known as the third rationalization program.

One of the important factors receiving more and more attention from steel industrialists is the development of an efficient personnel administration program, which, with the cooperation of the workers, is greatly improving labor productivity.

\section{Domestic Market}

The high level of activities in the field of construction, industrial machinery, containers and durable goods manufactures such as automobiles, office and household utensils, etc. brought a sharp increase in steel requirements during 1960. The situation is quite different from the prosperity in 1956 when the increased demand for finished steel was mainly the result of the favorable turn in the shipbuilding industry which exported ships in large quantity. At the same time, efforts have been made to stabilize the steel price under the collective sales system.

The apparent crude steel consumption per capita in 1960 was $207 \mathrm{~kg}$ as compared with $160 \mathrm{~kg}$ in 1959 . Table III shows the shipment of ordinary rolled steel in the years 1959 and 1960 .

As will be seen from the table, a big increase is noted in steel shipments for secondary steel products, machines and tools, especially electric machinery and automobiles, construction and merchant.

Delivery of special steel to domestic industries in 1960 totalled 1.1 million metric tons, an increase of $40.0 \%$ from 1959 shipments. Requirements of machinery and automobile manufacturers remarkably increased in 1960, taking respectively $19 \%$ and $16 \%$ of the total special steel shipments.

Table III. Shipment by market classification

(Unit : 1,000 metric tons)

\begin{tabular}{l|r|r} 
& 1959 & 1960 \\
\hline Export & 1,109 & 1,660 \\
Coal mining & 103 & 107 \\
Petroleum refining & 28 & 53 \\
Iron \& steel manufacture & 2,852 & 3,520 \\
Shipbuilding & 1,211 & 1,321 \\
Machine \& tools & 1,561 & 2,009 \\
Chemical manufacture & 105 & 119 \\
Construction & 1,104 & 1,402 \\
Transportation \& warehouse & 254 & 278 \\
Electric power & 61 & 66 \\
Government \& public demand & 53 & 66 \\
Other industries & 596 & 742 \\
Merchants & 2,507 & 3,557 \\
$\quad$ Total & 11,454 & 14,859 \\
\end{tabular}

\section{Export}

Exports of iron and steel have been of considerable importance to Japan, even in the years prior to 1940 . A much greater importance is attached today, however, to the export of iron and steel because steel, in addition to machinery and textiles, is one of the big export items capable of helping the Japanese economy to become self-supporting.

Prior to 1940,10 to $15 \%$ of Japan's crude steel production was exported. Subsequent to the postwar reconstruction period, export of steel expanded to a point where it absorbed $15-25 \%$ of the production.

The export of iron and steel varies from year to year, accounting for 10 to $20 \%$ of the total export from Japan. If the indirect export covering machines and the like is included, it amounts 
to about $35 \%$ of the total, thereby contributing much to the improvement of the balance of international accounts for Japan.

In the years 1956 to 1957 the iron and steel available for export was remarkably decreased because of the vigorous demand at home. However, since 1958 steel export has considerably increased thanks to the efforts to this end.

The export of iron and steel amounted to 2.5 million tons or 428 million dollars in 1960, showing an increase of $39 \%$ in quantity and an increase of $48 \%$ in value both as compared with 1959.

As for the export market, the demand from the U.S.A. has rapidly been increased since 1958, and in 1960 it accounted for $23 \%$ of the total export of iron and steel from Japan. The export to Australia and Southeast Asiatic countries such as India and the Philippines was remarkably increased.

The export of Japanese iron and steel products during 1960, by countries of destination, is shown in Table $\mathrm{V}$.

Table IV. Iron and steel exports since 1948 (Unit : 1,000 tons of crude steel equivalent)

\begin{tabular}{crc} 
& Exports & $\begin{array}{c}\text { Percentage to crude } \\
\text { steel production }\end{array}$ \\
\hline 1948 & 42 & 2.5 \\
1949 & 288 & 9.3 \\
1950 & 727 & 15.0 \\
1951 & 1,269 & 19.5 \\
1952 & 1,988 & 28.5 \\
1953 & 1,035 & 13.5 \\
1954 & 1,465 & 18.9 \\
1955 & 2,305 & 24.5 \\
1956 & 1,570 & 14.1 \\
1957 & 1,219 & 9.7 \\
1958 & 2,122 & 17.5 \\
1959 & 2,091 & 12.6 \\
19000 & 2,987 & 13.5
\end{tabular}

Table V. Export by countries of destination

(Unit: 1,000 metric tons)

\begin{tabular}{|c|c|c|}
\hline Destination & Quantity & $\%$ \\
\hline 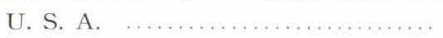 & 583 & 23.3 \\
\hline India $\quad \ldots \ldots \ldots \ldots \ldots \ldots \ldots \ldots \ldots \ldots \ldots \ldots \ldots \ldots$ & 293 & 11.7 \\
\hline Australia ............................. & 277 & 11.0 \\
\hline Philippines $\ldots \ldots \ldots \ldots \ldots \ldots \ldots \ldots \ldots$ & 150 & 6.0 \\
\hline Thailand $\ldots \ldots \ldots \ldots \ldots \ldots \ldots \ldots \ldots \ldots \ldots$ & 136 & 5.4 \\
\hline Formosa $\quad \ldots \ldots \ldots \ldots \ldots \ldots \ldots \ldots \ldots \ldots \ldots \ldots \ldots \ldots$ & 111 & 4.4 \\
\hline Argentina $\quad \ldots \ldots \ldots \ldots \ldots \ldots \ldots \ldots \ldots \ldots \ldots$ & 80 & 3.2 \\
\hline 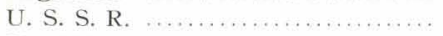 & 74 & 3.0 \\
\hline Singapore $\quad \ldots \ldots \ldots \ldots \ldots \ldots \ldots \ldots \ldots \ldots$ & 74 & 3.0 \\
\hline Burma $\ldots \ldots \ldots \ldots \ldots \ldots \ldots \ldots \ldots \ldots \ldots \ldots \ldots \ldots$ & 68 & 2.7 \\
\hline Canada $\ldots \ldots \ldots \ldots \ldots \ldots \ldots \ldots \ldots \ldots \ldots \ldots \ldots \ldots \ldots$ & 67 & 2.7 \\
\hline Malaya $\ldots \ldots \ldots \ldots \ldots \ldots \ldots \ldots \ldots \ldots \ldots \ldots \ldots \ldots \ldots$ & 56 & 2.2 \\
\hline E. Pakistan $\ldots \ldots \ldots \ldots \ldots \ldots \ldots \ldots \ldots \ldots \ldots \ldots \ldots$ & 55 & 2.2 \\
\hline 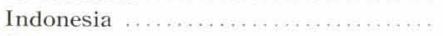 & 50 & 2.0 \\
\hline 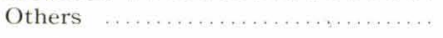 & 433 & 17.2 \\
\hline 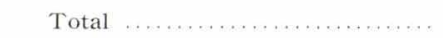 & 2,507 & 100.0 \\
\hline
\end{tabular}

\section{Wages and Labor Conditions}

The recent survey by the Japan Iron \& Steel Federation revealed that wages paid by the 55 member companies (accounting for $93.8 \%$ of the national total in terms of crude steel production) to their 135,000 production workers during 1960 averaged Y32,722 per capita per month.

This average wage per capita has been making a steady increase year after year, registering an increase of $43.3^{\circ}$ in 1960 over that in 1955, while CPI has been increased by $7.9 \%$ in those five years.

In addition to the monthly wages, it has been an established practice that workers are paid a bonus twice a year, namely, the mid-summer bonus and the year-end bonus, of which the average amount per capita per month was 18,806 in the year 1960.

Furthermore, apart from the facilities as prescribed for by laws and regulations, most companies voluntarily provide their employees with well-furnished houses and fully-equipped facilities such as hospitals, gymnasiums, clubs, etc., at low cost or even free of charge, as explained later. All the costs for operating and maintaining these facilities are borne by each company under the heading of cost for employees' welfare.

The total amount of all the expenditures borne by the companies for their employees during 1960 was as stated below, including the expenditures for legal welfare facilities and retirement allowances, which will be described further on.

\section{Structure of Labor Cost} allowance)

(2) Bonus:

3) Legal welfare expenditures

(4) Non-obligatory welfare expenditures: (inclusive of allowances in kind and retirement grant Total of (1) through (4): $\stackrel{\$}{\$} \quad 68.7$ $5.6 \quad 18.7$ $1.3 \quad 4.2$ $2.5 \quad 8.4$ $30.0 \quad 100.0$

Note: The amount shown represents the average per capita per week.

The working days are generally 6 days a week, and working hours are 7 hours a day. In addition to the regular weekly holidays, the workers are granted a total of 15 extra holidays annually including 9 national holidays and 6 other holidays such as the company's anniversary day and the year-end to new year's vacation.

The paid vacation ranges from 14 to 20 days annually, depending upon the years of service of each individual worker.

The company pension system has not been established as yet, but in its stead is a widely-adopted company retirement grant system under which the employee is provided with a lump sum payment when he retires from the company. 
In principle, the longer the period of his service the greater will be the sum of his retirement grant. A worker with 30 years of continued service with a company, for example, is entitled to a retirement allowance in an amount equal to 30 times the monthly pay he is getting at the time of his retirement.

The nature of the duties and functions performed by the individual worker is changing with the progress of modernization of the steel plant. To meet this situation, enthusiastic studies are now being made on Industrial Engineering (I.E.) with a view to standardizing the work.

This trend is affecting the wage system of the iron and steel industry.

The wage of the iron and steel production worker has always been on a higher level than that of workers in other industries. The data prepared by the Ministry of Labor indicates that the average wage per capita of production workers in the iron and steel industry has been about 80 to $90 \%$ higher for these years than that of production workers in the entire manufacturing industry in Japan.

\section{Safety and Health}

\section{Safety}

The number of accidents in the Japanese iron and steel industry has been decreasing gradually in recent years. Especially, the frequency of accident in leading steel plants in Japan is so low as to be sufficiently comparable to that of other leading iron and steel producing countries of the world.

Each steel company has in each of its plants a safety committee composed of members from both management and employees to promote and develop the safety movement. Owing to the activities of the safety committee in each plant, a rapid improvement has been achieved in safety efficiency since 1950 .

\section{Health}

Of the iron and steel companies in Japan, the leading companies maintain their own fully-equipped hospitals. Besides, most of the steel plants have within the premises of the plants dispensaries or clinics to provide first aid treatment and medical care to employees who get injured or ill during working hours. A systematic personal health administration is maintained in every plant or shop and various activities for betterment of the employee's health are being promoted by the health committee composed of management and union representatives.

All the companies are required by law to effect an annual medical examination of all employees primarily for the purpose of diagnosing tubercular cases at an early stage. Since this disease requires a considerable length of time for complete recovery, many of the companies grant exceptions to their sick leave regulations for those employees who have become tuberculosis patients, whereby they are allowed longer leaves than in other cases.

With the consolidation of the laws and regulations pertaining to health and sanitation, each company is making every effort to prevent vocational diseases and establish a healthy working environment for its employees, and has thus far been successful in accomplishing satisfactory results.

\section{Education and Training}

Since the introduction of TWI (Training Within Industry) into Japan in 1950 as a supervisory training course, education and training of the employees based on the said educational program as well as MTP (Management Training Program) as the training course for management have rapidly become popular among the steel companies in Japan. Completion of one of these training courses is now one of the important prerequisites for employees promoted to supervisory positions. What is more, some companies plan and prepare their own training and education programs in various forms, such as Supervisors Classes, in accordance with their respective needs.

These courses, which are not the mere followup courses of TWI or MTP but are in a more advanced form including training programs in safety, quality and process control, are producing quite effective results.

With the modernization of the plant equipment, the refreshed training for the first line supervisors and group leaders has been a matter of great urgency for these years. The main steel companies are not only giving 6 month to 1 year technical and management training courses to the first and second line supervisors at present but are also planning to establish special training programs for young employees for the purpose of cultivating supervisors of a new type with due capability to cope with the new age.

The system of apprenticeship for cultivation of skilled workers to systematically educate and train the graduates of the junior high school for a period of 3 years, based on the training standards provided for in the Vocational Training Law, is practiced by 22 companies at 42 plants in the iron and steel industry as of March 1960. Under these programs, young apprentices are now educated and trained in the maintenance trades as well as in the main productive trades of pig iron making, steelmaking and rolling. 


\section{$X$. Companies}

The Japan Iron and Steel Co., Ltd., a merger company with governmental participation, played a leading role in the prewar iron and steel industry of this country. Under the Law for Elimination of Excessive Concentration of Economic Power of 1948, this company was split into two companies, i.e., Yawata Iron \& Steel Company and Fuji Iron \& Steel Company. These two companies were then established as private enterprises. Before the war the other integrated plants belonged to Nippon Kokan K. K., Nakayama Steel Works and Amagasaki Iron \& Steel Manufacturing Company. Recently, however, four leading companies have joined the integrated group. They are Kawasaki Steel Corporation, Sumitomo Metal Industries, Ltd., Kobe Steel Works, Ltd. and Osaka Steel Manufacturing Co., Ltd.

At present, 9 companies have blast furnaces, 12 have open hearth furnaces, and 58 manufacture steel with electric furnaces. In addition to these companies, there are 506 small enterprises engaged in rolling, casting, forging and other processes of steel making. The percentage share of the above mentioned group of companies, in the total iron and steel production of 1960 , broken down into pig iron, crude steel and rolled steel output, is shown in the following table.

Table VI.

\begin{tabular}{lrcccc} 
& $\begin{array}{c}\text { No. of } \\
\text { companies }\end{array}$ & $\begin{array}{c}\text { Pig } \\
\text { iron }\end{array}$ & $\begin{array}{c}\text { Crude } \\
\text { steel }\end{array}$ & $\begin{array}{c}\text { Ordinary } \\
\text { rolled } \\
\text { steel }\end{array}$ & $\begin{array}{c}\text { Special } \\
\text { rolled } \\
\text { steel }\end{array}$ \\
\hline Production $(1,000 \mathrm{~m} / \mathrm{t}$ ) & & 11,896 & 22,138 & 15,675 & 1,169 \\
Blast furnace companies & 9 & $94 \%$ & $74 \%$ & $72 \%$ & $24 \%$ \\
Open hearth companies & 12 & 1 & 12 & 11 & 12 \\
Electric furnace companies & 58 & 1 & 10 & 8 & 61 \\
Other companies & 506 & 4 & 4 & 9 & 3 \\
$\quad$ Total & 585 & 100 & 100 & 100 & 100
\end{tabular}

The names of the principal iron and steel companies are listed at the end of this chapter, and the locations of the leading plants are illustrated on the map.

Table VII. Principal iron and steel companies in Japan

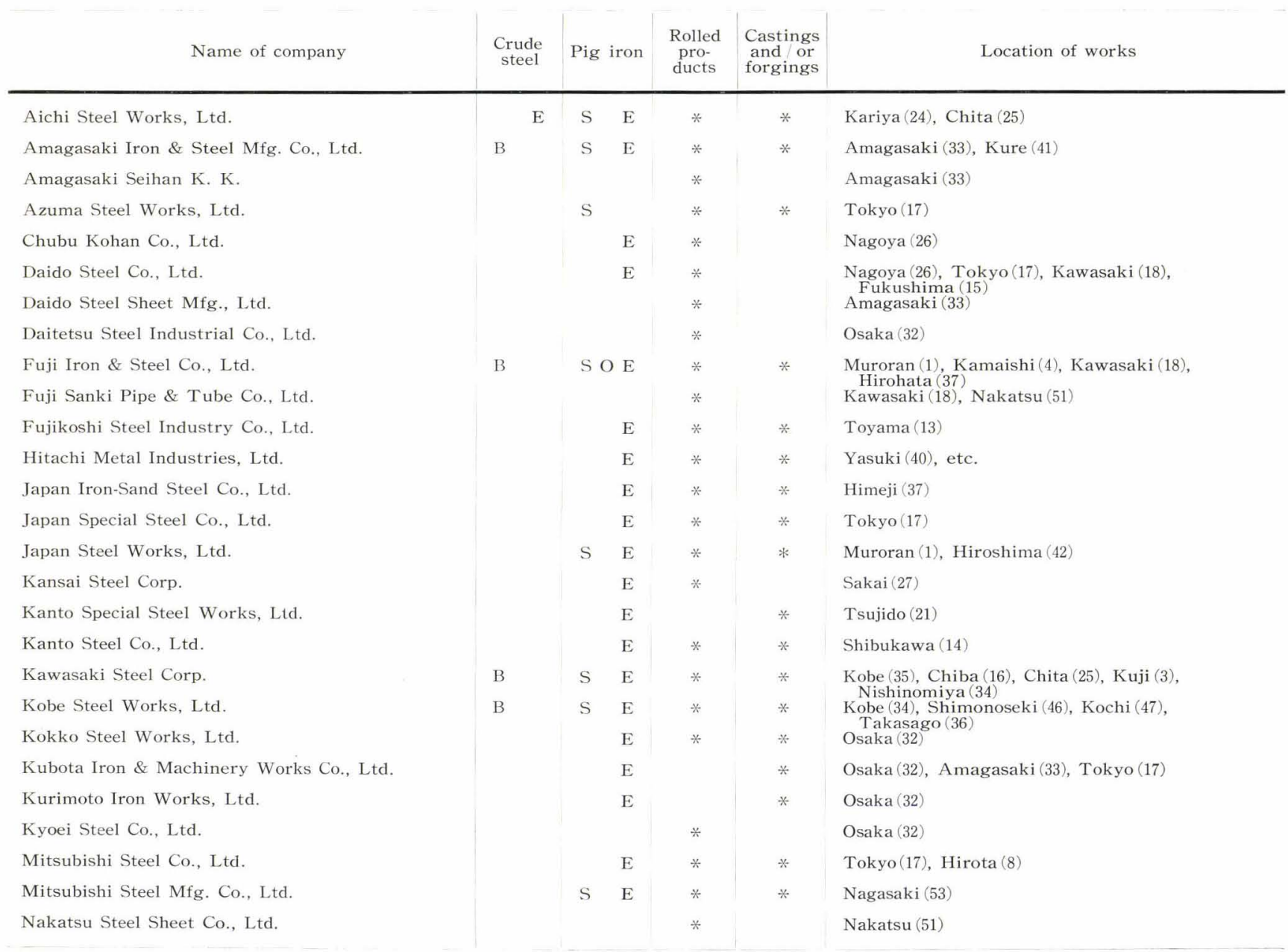


Nakayama Steel Products Co., Ltd.

Nakayama Steel Works, Ltd.

Nihon Cast Steel Co., Ltd.

Nippon Kinzoku Co., Ltd.

Nippon Kogyo Steel Works Co., Ltd.

Nippon Kokan K. K.

The Nippon Koshuha Steel Co., Ltd.

Nippon Metal Industry Co., Ltd.

Nippon Stainless Steel Co., Ltd.

Nippon Yakin Kogyo Co., Ltd.

Nishinomiya Kohan K. K.

Nisshin Steel Works Co., Ltd.

Nissin Seiko K. K.

Nisso Steel Mfg. Co., Ltd.

Osaka Shipbuilding Co., Ltd.

Osaka Steel Mfg. Co., Ltd.

Osaka Special Steel Mfg. Co,, Ltd.

Otani Heavy Industrial Co., Ltd.

Otani Steel Works, Ltd.

Sanyo Special Steel Co., Ltd.

Shimura Kako Co., Ltd.

Sumitomo Electric Industries, Ltd.

Sumitomo Metal Industries, Ltd.

Tohoku Metal Industries, Ltd.

Tohoku Special Steel Works, Ltd,

Tokai Steel Works, Ltd.

Tokushu Seiko Co., Ltd.

Tokyo Seitetsu K. K.

Tosa Steel Mill Co., Ltd.

Toshiba Steel Co., Ltd.

Toto Steel Mfg. Co., Ltd.

Toyo Kolıan Co., Ltd.

Yamato Steel Works, Ltd.

Yawata Iron \& Steel Co., Ltd.

Yawata Steel Tube Co., Ltd.

Yodogawa Steel Works, Ltd.

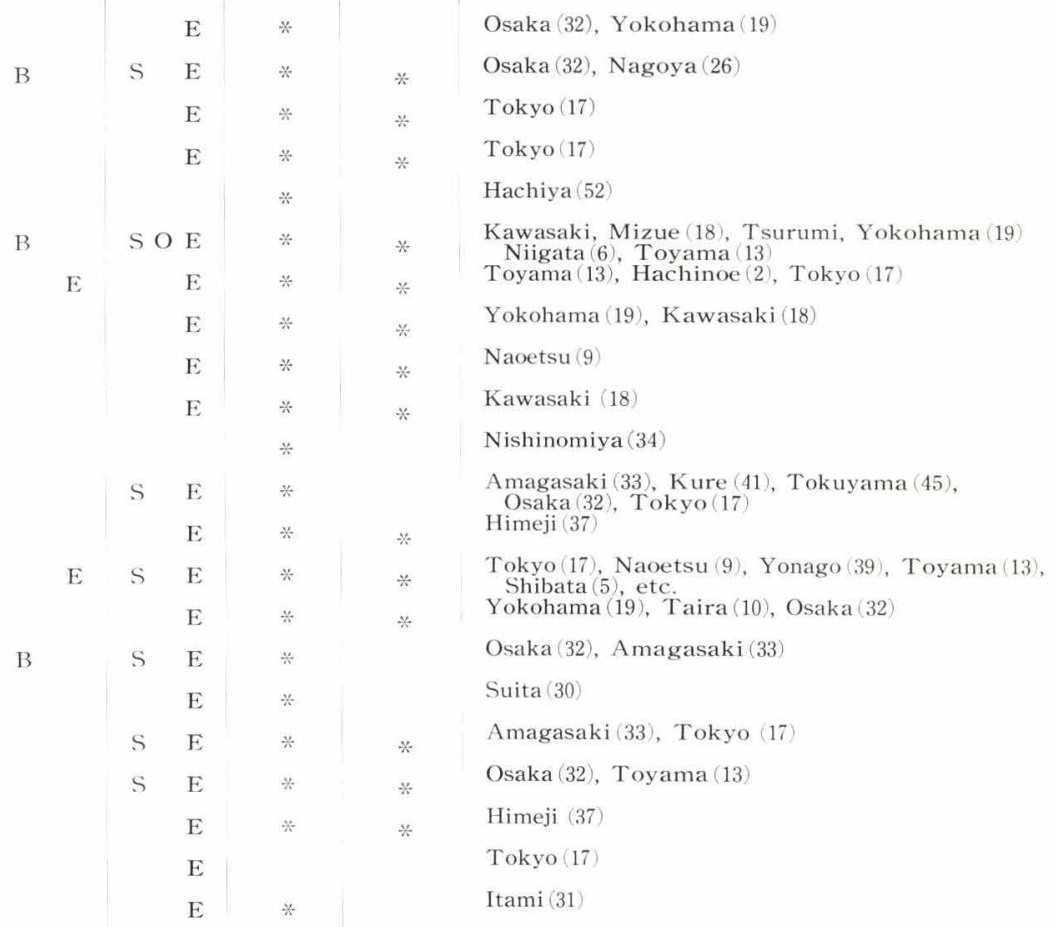

B

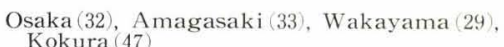
Sendai $(7)$

Sendai $(7)$

Wakamatsu (49)

Kawasaki (18), Tokyo (17)

Tokyo (17)

Kochi (47), Kure (41)

Tokyo (17)

Tokyo (17), Chigasaki (22), Toyohashi (23)

Kudamatsu (44)

Osaka $(32)$

Yawata (50), Hikari (43), Sakai (27)

Tokyo (17), Hikari (43), Yawata (50)

Osaka (32), Izumiotsu (27), Kure (41) 
Location of Japanese Iron and Steel Works

$\begin{aligned} 1 & \text { Muroran } \\ 2 & \text { Hachinoe } \\ 3 & \text { Kuji } \\ 4 & \text { Kamaishi } \\ 5 & \text { Shibata } \\ 6 & \text { Niigata } \\ 7 & \text { Sendai } \\ 8 & \text { Hirota } \\ 9 & \text { Naoetsu } \\ 10 & \text { Taira } \\ 11 & \text { Hitachi } \\ 12 & \text { Mito } \\ 13 & \text { Toyama } \\ 14 & \text { Shibukawa } \\ 15 & \text { Fukushima } \\ 16 & \text { Chiba } \\ 17 & \text { Tokyo } \\ 18 & \text { Kawasaki } \\ 19 & \text { Yokohama } \\ 20 & \text { Sagami } \\ 21 & \text { Tsujido } \\ 22 & \text { Chigasaki } \\ 23 & \text { Toyohashi } \\ 24 & \text { Kariya } \\ 25 & \text { Chita } \\ 26 & \text { Nagoya } \\ 27 & \text { Sakai }\end{aligned}$

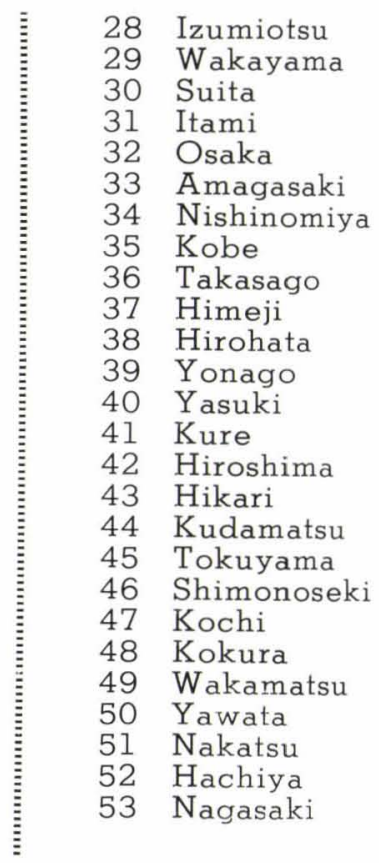

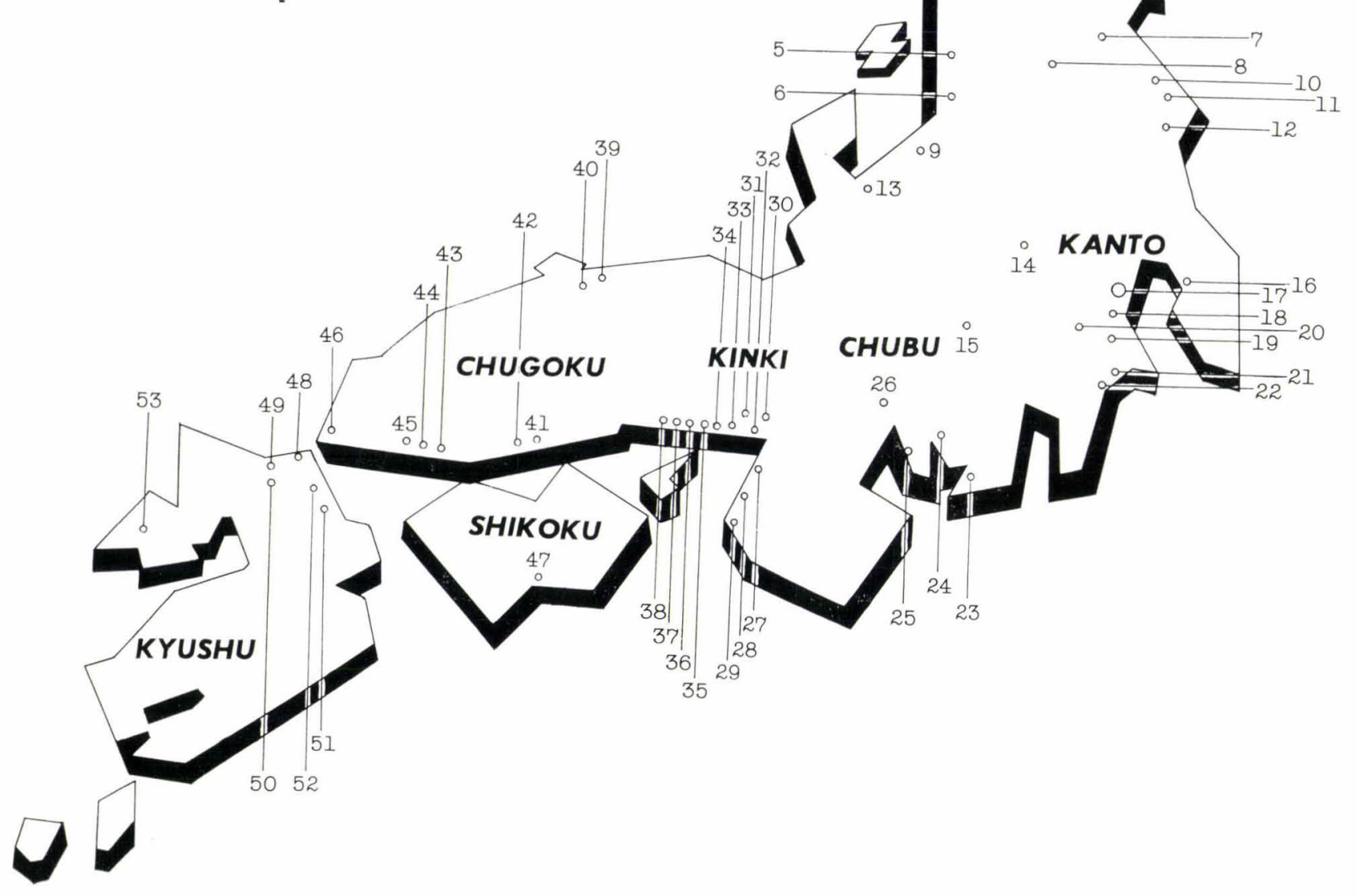

